\title{
PENGARUH KONSENTRASI ASAM ASETAT DAN WAKTU EKSTRAKSI TERHADAP MUTU KOLAGEN LIMBAH KULIT IKAN NILA HITAM
}

\author{
Latif Sahubawa dan A.B. Naro Putra \\ Jurusan Perikanan Fakultas Pertanian Universitas Gadjah Mada \\ Email: Latifsahubawa2004@yahoo.com
}

\begin{abstract}
The objective of the research was studied the effect of acetic acid concentration and extraction time on the collagen quality of black tilapia leather. Black tilapia leather was processed into collagen as an alternative to increasing value-added of fisheries industry waste. Collagen of black tilapia was extracted by the treatment of acetic acid molarity, each: $0.25 \mathrm{M}, 0.50 \mathrm{M}$, and $0.75 \mathrm{M}$ (A factor) and extraction time of 16 and 48 hours (B factor). Based on the analysis of variance is known that the interaction of those treatments $(A B)$ didn't significantly effect on the yield ( $p>0.05$ ). Collagen extraction of tilapia leather with $0.75 \mathrm{M}$ of acetic acid at 16 hours, produces the greatest yield $(5.97 \%)$, with denaturation temperature is $35.75^{\circ} \mathrm{C}$, and quantitative composition of glisine, alanine, and glutamic amino acids were: $5395.82 \mathrm{ppm}$ (52.99\%), $2979.15 \mathrm{ppm}$ (22.08\%), and $1684.42 \mathrm{ppm}(7.45 \%)$. Based on the analysis of SDS-PAGE is known that the collagen contained were a component and $\beta$ component, so that collagen of tilapia leather has type I collagen.
\end{abstract}

Key words: acetic acid, collagen, leather, molarity, black tilapia, extraction time

\begin{abstract}
ABSTRAK
Tujuan penelitian adalah mengkaji pengaruh konsentrasi asam asetat dan waktu ekstraksi terhadap mutu kolagen kulit nila hitam. Kulit nila hitam dapat diolah menjadi kolagen sebagai alternatif peningkatan nilai tambah limbah industri perikanan. Kolagen dari kulit nila hitam diekstraksi dengan larutan asam asetat $\left(\mathrm{CH}_{3} \mathrm{COOH}\right)$ molaritas: $0,25 \mathrm{M} ; 0,50 \mathrm{M}$; dan 0,75 M (faktor A) dan waktu ekstraksi 16 dan 48 jam (fakor B). Dari hasil analisis varian, diketahui bahwa interaksi dari perlakuan konsentrasi asam asetat dan waktu ekstraksi $(A B)$ tidak berpengaruh nyata terhadap rendemen kolagen $(p>0,05)$. Ekstraksi kolagen dari kulit nila hitam dengan perlakuan asam asetat 0,75 M selama 16 jam menghasilkan rendemen kolagen yang terbesar $(5,97 \%)$, dengan suhu denaturasi $35,75^{\circ} \mathrm{C}$ dan komposisi kuantitatif asam amino glisin, alanin, dan asam glutamat, berturut-turut: 5395,82 ppm (52,99\%), 2979,15 ppm $(22,08 \%), 1684,42 \mathrm{ppm}(7,45 \%)$. Berdasarkan hasil analisis SDS-PAGE, diketahui bahwa kolagen sampel kulit nila hitam mengandung ikatan rantai- $\alpha$ dan rantai- $\beta$ sebagai kolagen tipe-I.
\end{abstract}

Kata kunci: asam asetat, kolagen, kulit, molaritas, nila hitam, waktu ekstraksi 


\section{PENGANTAR}

Pemanfaatan limbah kulit ikan sebagai bahan baku kolagen merupakan salah satu alternatif peningkatan nilai tambah limbah industri perikanan, sekaligus mengurangi dampak negatif (pencemaran) terhadap lingkungan hidup. Kolagen, umumnya diisolasi dari jaringan kulit hewan darat (sapi dan babi), tetapi sering didapatkan konsumen yang terjangkit bovine spongiform encephalopathy (BSE) serta penyakit kuku dan mulut akibat menggunakan kolagen yang diproduksi dari jaringan kulit sapi (Yamaguchi, 2002), serta dari jaringan babi yang diharamkan oleh masyarakat muslim dunia. Kondisi ini memberikan peluang besar untuk pemanfaatan kulit ikan sebagai sumber kolagen alternatif di bidang industri pangan dan nonpangan, terutama pada industri farmasi.

Kolagen diketahui mempunyai banyak manfaat pada dunia medis dan farmasi. Pemanfaatan dan aplikasi kolagen antara lain untuk penanganan penderita hipertensi, permasalahan urinari, sakit yang berkaitan dengan osteoarthritis, rekayasa jaringan untuk implantasi pada manusia, dan penghambatan penyakit angiogenic, seperti komplikasi diabetes, obesitas, dan arthritis (Rehn et al., 2001). Kolagen juga dapat diaplikasikan dalam bidang pangan (edible casing), kosmetik (krim kulit, shampo, produk-produk perawatan rambut, cat kuku), dan medis (perbanyakan plasma/pemekar, agen hemostatik, material benang bedah, perbaikan katup prostensis, perbaikan selaput mata, hemodialisis, tulang buatan, pembentukan oksigen membram, dan pemulihan operasi organ-organ yang rusak (esofagus, trakea) (Chvapil, 1979).

Penelitian isolasi kolagen dari spesies dan bagian tubuh ikan yang berbeda telah banyak dilakukan. Ekstraksi kolagen kulit ikan perch Nil (usia muda), diperoleh rendemen sebesar $63,1 \%$ dan $58,7 \%$ (usia dewasa); pada makarel chub, hiu bullhead, dan kakap Jepang didapatkan rendemen kolagen masing-masing: $49,8 \%$; $50,1 \%$; dan 51,4\% (Jongjareonak et al., 2004). Pada ikan cod dan baltic cod didapatkan kolagen masing-masing: 71,2\% dan 74,4\% (Sadowska, et al. 2003). Pada kulit sotong, diperoleh acid soluble collagen (ASC) sebesar 2\% dan pepsin soluble collagen (PSC) sebesar 35\% (Nagai et al., 2001). Perbedaan spesies, habitat dan perlakuan pada proses ekstraksi berpengaruh nyata pada jumlah rendemen, karakteristik, dan komposisi molekul kolagen. Penelitian tentang kolagen dari spesies ikan domestik masih terbatas sehingga perlu dikaji secara mendalam sumber-sumber kolagen alternatif potensial.

Penelitian tentang kolagen yang berasal dari spesies ikan air tawar yang hidup didaerah tropis jarang dilakukan. Ikan nila merupakan salah satu spesies ikan air tawar potensial yang hidup didaerah tropis. Berdasarkan hasil penelusuran pustaka diatas dan untuk memenuhi permintaan industri pangan dan nonangan (terutama di bidang farmasi) terhadap konsumsi kolagen yang berkualitas dan dapat diterima semua kalangan, maka perlu dilakukan penelitian mengenai kolagen kulit nila. Penelitian bertujuan untuk mempelajari pengaruh konsentrasi larutan asam asetat dan lama waktu ekstraksi terhadap mutu kolagen kulit nila hitam, sebagai kolagen potensial yang berkualitas serta aman dan halal dikonsumsi masyarakat untuk dijadikan sumber alternatif pengganti kolagen dari jaringan babi dan sapi.

\section{Bahan dan Alat}

Bahan baku utama penelitian yaitu kulit nila hitam kering yang diperoleh dari pengumpul kulit nila di Kota Solo, Jawa Tengah. Bahan-bahan kimia yang digunakan untuk analisis, antara lain: $\mathrm{NaOH}, \mathrm{H}_{2} \mathrm{O}, \mathrm{CH}_{3} \mathrm{COOH}, \mathrm{NaCl}$, acrylamide, amonium persulfat, Coomassie Blue R-250, etilendiamintetraasetat acid, $\mathrm{Na}_{2}$ EDTA. $2 \mathrm{H}_{2} \mathrm{O}$, $\mathrm{C}_{3} \mathrm{H}_{8} \mathrm{O}_{3}$, glisin, $\mathrm{HCl}, \beta$-mercaptoetanol, $\mathrm{CH}_{3} \mathrm{OH}$, Protein MolecularWeight Standards (e.g., BioRad 161-0318, Prestained SDS-PAGE standards 
broad range, 209-7 kD, sodium dodecyl sulfate, sodium salt, $N, N, N^{\prime}, N^{\prime}$-Tetramethylethylenendiamine, tris base, $\mathrm{H}_{3} \mathrm{BO}_{3}$, bromocresol green, etanol (95\%), $\mathrm{HCl}$ pekat, methyl-red, $\mathrm{H}_{2} \mathrm{SO}_{4}$ pekat, Kjeldahl digestion tablets, $\mathrm{K}_{2} \mathrm{SO}_{4^{\prime}} \mathrm{CuSO}_{4^{\prime}}$ $\mathrm{TiO}_{2}$; tris hidroksimetil aminomethane, petroleum eter, fenol, $\mathrm{N}_{2}$ air deionisasi, trimetilamin, fenilisotiosianat, dan buffer fosfat $\mathrm{pH}$ 7,4.

\section{Metode}

\section{Uji Proksimat Sampel Kulit Nila Hitam Kering}

Uji proksimat sampel kulit nila hitam kering terdiri dari: kadar protein (\%), air (\%), abu (\%), dan lemak (\%) (Nielson et al., 2003).

\section{Isolasi Kolagen}

Proses isolasi kolagen dari sampel kulit nila hitam menggunakan metode Ogawa et al. (2004) dengan modifikasi. Semua prosedur isolasi kolagen dilakukan pada suhu kamar, kecuali untuk sentrifugasi $\left(4^{\circ} \mathrm{C}\right)$, dengan tahap-tahap sebagai berikut.

a. Persiapan bahan baku utama (sampel kulit nila hitam kering dipotong-potong dengan ukuran $1 \mathrm{~cm} \times 1 \mathrm{~cm}$ ).

b. Penghilangan protein non-kolagen dengan cara merendam sampel yang telah dipotong-potong dalam larutan $\mathrm{NaOH}$ 0,1 M selama 24 jam dengan perbandingan bobot kulit dan volume larutan 1:20 (b/v). Kulit nila dicuci dengan aquades hingga $\mathrm{pH}$ sampel mendekati atau mencapai $\mathrm{pH} 7$.

c. Proses ekstraksi kolagen dilakukan dengan larutan $\mathrm{CH}_{3} \mathrm{COOH}$ pada konsentrasi $0,25 \mathrm{M} ; 0,5 \mathrm{M}$ dan $0,75 \mathrm{M}$ (b/v 1:10) serta waktu inkubasi 16 dan 48 jam. Hasil ekstraksi disaring dengan saringan plastik untuk memisahkan residu dan ekstrak (supernatan). Supernatan dipresipitasi dengan cara menambahkan $\mathrm{NaCl}$ sampai konsentrasi akhir larutan mencapai $0,9 \mathrm{~mol} \mathrm{dm}^{3}$ sehingga didapatkan presipitat kolagen (proses salting-out).

d. Presipitat dibiarkan selama 24 jam, kemudian disentrifugasi pada $3500 \mathrm{rpm}$ dan suhu $4^{\circ} \mathrm{C}$ selama 20 menit. Kolagen yang didapatkan dari hasil sentrifugasi kemudian di dialisis, dengan cara kolagen dilarutkan dalam asam asetat 0,5 M (b/v: 1:10), kemudian dimasukkan ke dalam membran selofan.

e. Membran yang berisi kolagen direndam dalam larutan asam asetat 0,1 M. Larutan asam asetat diganti setiap 3 jam dengan larutan asam asetat 0,1 M yang baru. Setelah dua kali dilakukan penggantian larutan asam asetat $0,1 \mathrm{M}$, membran yang berisi kolagen direndam dalam aquades yang diganti setiap 3 jam sampai $\mathrm{pH}$ aquades yang digunakan menjadi 5 atau lebih. Kolagen pascadialisis selanjutnya diliofilisasi (freeze drying) selama 12 jam dalam wadah-wadah kecil terpisah yang mudah dikeringkan.

\section{Pengukuran Viskositas dan Suhu Denaturasi}

Analisis viskositas dan suhu denaturasi mengikuti metode yang dilakukan Ogawa et al. (2004), yakni dengan melarutkan 20 mg kolagen kering ke dalam $100 \mathrm{ml}$ asam asetat 0,1 M. Viskositas dianalisis dengan alat Cannon-Fenske Viscometer, dimana viskositas larutan kolagen diukur dengan menghitung waktu alir larutan kolagen dalam pipa kapiler viscometer, dikurangi waktu alir larutan asam asetat $0,1 \mathrm{M}$. Viskositas Spesifik $\left(\eta_{\mathrm{sp}}\right)$ dihitung menggunakan persamaan $\left(\mathrm{t}-\mathrm{t}_{0}\right) / \mathrm{t}_{\sigma^{\prime}}$ dengan asumsi bahwa densitas larutan dan solven adalah sama ( $\mathrm{t}=$ efflux time larutan kolagen dan $\mathrm{t}_{0}=$ efflux time solven).

$$
\eta_{\mathrm{sp}}=\left(\mathrm{t}-\mathrm{t}_{0}\right) / \mathrm{t}_{0}
$$

Ket.:

$\eta_{\mathrm{sp}}=$ viskositas spesifik larutan

$\mathrm{t}=$ waktu alir larutan kolagen (dalam detik)

$\mathrm{t}_{0} \quad=$ waktu alir pelarut (dalam detik)

a. Viskositas tereduksi $\left(\mathrm{c}_{\mathrm{sp}} / \mathrm{c}\right)$ kemudian diplotkan melawan c (c $=$ konsentrasi 
$\operatorname{protein}(\mathrm{g} / \mathrm{dl}))$. Viskositastereduksi $\left(\mathrm{c}_{\mathrm{sp} / \mathrm{c}}\right)$ sebagai suatu ukuran perbandingan viskositas terhadap konsentrasi larutan kolagen dapat dihitung dengan membagi viskositas spesifik dengan konsentrasi kolagen $(0,02 \mathrm{~g} / \mathrm{dl})$.

b. Kurva denaturasi termal didapatkan dari hasil pengamatan perubahan viskositas. Delapan mililiter larutan kolagen $(0,02 \mathrm{~g} / \mathrm{dl})$ diinkubasi pada suhu $30-42^{\circ} \mathrm{C}$, yang dinaikkan perlahan dan dipertahankan selama 30 menit. Kurva denaturasi termal larutan kolagen didapatkan dengan memplotkan viskositas tereduksi ç sp $_{\text {c }}$ c melawan suhu. Suhu denaturasi, $\mathrm{Td}-V$, diekspresikan sebagai suhu pertengahan antara garis terekstrapolasi untuk kolagen asal dan dengan kolagen yang sepenuhnya terdenaturasi pada plot $c_{s \beta} / c$ versus suhu. Denaturasi dapat diartikan sebagai perubahan atau modifikasi struktur sekunder, tertier dan kuartener molekul protein, tanpa terjadinya pemecahan ikatan kovalen. Caranya, larutan kolagen kulit nila hitam sebanyak $8 \mathrm{ml}, 0,02 \mathrm{~g} / \mathrm{dl}$ (20 mg dalam $100 \mathrm{ml}$ larutan asam asetat) dialirkan melalui kapiler viskometer pada suhu $30-42^{\circ} \mathrm{C}$, kemudian pengamatan viskositas dengan mengukur waktu alir pada suhu yang sama.

\section{Analisis Tipe Kolagen (Elektroforesis)}

Tipe kolagen dianalisis menggunakan sodium dodecyl sulfate-polyacrylamide gel electrophoresis (SDS-PAGE) yang mengacu pada buku panduan Sambrook dan Russel (2001).

a. Persiapan SDS-PAGE dimulai dengan preparasi sampel $10 \mu \mathrm{g}$ kolagen kering yang dilarutkan dalam $200 \mu$ l aquades. Campuran diaduk dengan magnetic stirrer. Sampel kolagen yang terlarut dicampur pada perbandingan 1:1 (v/v) dengan 10\% SDS.

b. Campuran gel SDS-PAGE dibuat pada konsentrasi 8\%. Masukkan gel ke dalam lempeng kaca, sampel beserta marker protein yang telah disiapkan diinjeksikan ke dalam sumuran yang tersedia. Sampel dimasukan sebanyak $10 \mu 1$ secara perlahan, sedangkan marker sebanyak $1 \mu 1$. Marker rainbow digunakan untuk memperkirakan bobot molekul protein.

c. Elektroforesis dijalankan pada 10-20 mA selama 30-60 menit. Setelah proses elektroforesis, gel diwarnai selama 8 jam dengan Coomassie blue R-250 0,05\% (b/v) dalam metanol 15\% (v/v) dan asam asetat $5 \%(\mathrm{v} / \mathrm{v})$, kemudian dihilangkan warnanya dengan metanol $30 \%(\mathrm{v} / \mathrm{v})$ dan asam asetat $10 \%(\mathrm{v} / \mathrm{v})$.

\section{Analisis Komposisi Asam Amino (Sudarmadji, 1996).}

a. Langkah pertama adalah melakukan pemotongan rantai kolagen menjadi residu asam amino, dengan cara tambahkan cuplikan 5 gram sampel ke dalam $20 \mathrm{ml} \mathrm{HCl} 6 \mathrm{~N}$ dan dihomogenkan.

b. Campuran selanjutnya dimasukkan ke dalam autoklaf pada suhu $110^{\circ} \mathrm{C}$ selama 12 jam.

c. Setelah suhu campuran sama dengan suhu ruang, campuran dinetralkan dengan larutan $\mathrm{NaOH} 6 \mathrm{~N}$, ditambahkan dengan $2,5 \mathrm{ml} \mathrm{Pb}$ asetat dan $1 \mathrm{ml}$ asam oksalat, kemudian disaring dengan rillex $0,45 \mu \mathrm{m}$, dan diinjeksikan ke dalam alat HPLC.

\section{Analisis Statistik}

Data rerata hasil pengamatan mutu kolagen kulit nila hitam dari masing-masing perlakuan: konsentrasi asam asetat $0,25 \mathrm{M}$; 0,50 M; dan 0,75 M dan waktu ekstraksi 16 jam dan 48 jam, dianalisis secara statistik menggunakan Rancangan Acak Lengkap 2 (dua) faktor dengan 3 (tiga) kali ulangan. Untuk mempelajari pengaruh perlakuan terhadap karakteristik kolagen, data hasil pengamatan dianalisis dengan analisis varian pada tingkat signifikansi $95 \%$. 


\section{PEMBAHASAN}

\section{Proksimat}

Hasil uji proksimat sampel kulit nila kering menunjukkan kadar protein 47,43\%; air 23,74\%; lemak 1,68\%; dan abu 3,01\%. Kadar protein sebesar $47,43 \%$ menunjukkan bahwa kulit nila dapat dijadikan sebagai bahan baku produk kolagen. Menurut Sadowska et al. (2003), rerata kandungan kolagen kulit secara umum sebesar 21,50\% (berat basah) dan $71,20 \%$ (berat kering).

\section{Rendemen (\%)}

Berdasarkan hasil analisis sampel kulit nila hitam, diperoleh rendemen kolagen kering berkisar antara 2,24\% - 5,97\%. Rendemen kering kolagen dari kulit nila yang diekstraksi dengan asam asetat, konsentrai 0,25M;0,50M; 0,75M pada selang waktu 16 jam dan 48 jam dapat dilihat pada Gambar 1. Hasil analisis sidik ragam menunjukkan bahwa perlakuan interaksi konsentrasi asam asetat dan waktu ekstraksi (AB) tidak berpengaruh nyata terhadap produksi rendemen kering sampel kulit nila hitam $(\mathrm{p}>0,05)$.

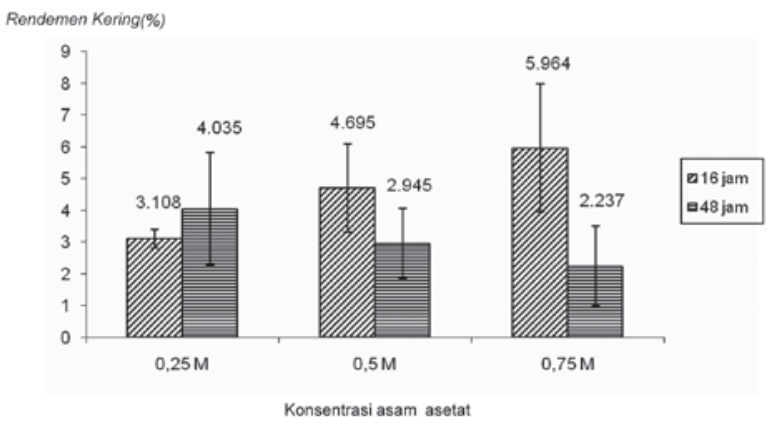

Gambar 1.

Rendemen kolagen (\%) sampel kulit nila hitam per perlakuan

Kadar rendemen kolagen dari beberapa jenis bahan baku diperlihatkan pada Tabel 1. Persentase rendemen kolagen kering sampel kulit nila hitam sebesar 5,97\%. Bila dibandingkan dengan rendemen kering kolagen sisik ikan karper, sisik sardine dan kulit cod, ternyata rendemen kering kolagen kulit nila hitam relatif kecil. Hal tersebut diduga karena adanya ikatan hidrogen yang kuat di dalam struktur kolagen kulit nila sehingga proses pemutusan ikatan hidrogen selama proses ekstraksi kolagen sulit terjadi. Ikatan hidrogen yang kuat berfungsi sebagai penstabil struktur kolagen triple-helix. Sifat ikatan yang kuat diduga terkait erat dengan habitat hidup ikan nila hitam yang berada pada daerah tropis.

\section{Viskositas $\left(\boldsymbol{\eta}_{\mathrm{sp}}\right)$}

Suhu, waktu, jenis enzim, asam dan basa kuat adalah faktor yang mempengaruhi pemotongan rantai/polimer protein. Makin tinggi dan banyaknya nilai faktor tersebut, maka jumlah potongan rantai polimer juga makin meningkat (Basmal et al, 2005). Dari Tabel 2, terlihat bahwa makin tinggi suhu, maka waktu alir yang diperlukan akan makin menurun. Menurunnya waktu alir disebabkan berkurangnya tahanan suatu cairan karena makin pendeknya rantai senyawa polimer yang disebabkan oleh suhu. Basmal et al. (2007), mengatakan bahwa viskositas adalah pernyataan tahanan dari suatu cairan untuk mengalir. Makin tinggi nilai viskositas suatu bahan, menandakan makin besar tahanan cairan bahan bersangkutan. Menurut Glicksman (1969), viskositas adalah daya aliran molekul dalam sistem larutan. Billmeyer (1962) menyatakan bahwa suatu senyawa polimer yang lebih pendek akan memiliki viskositas lebih rendah dibandingkan dengan senyawa polimer yang lebih panjang dari jenis yang sama. 
Tabel 1.

Perbandingan rendemen kolagen dari berbagai macam sumber

\begin{tabular}{|l|l|l|}
\hline \multicolumn{1}{|c|}{ Sumber Kolagen } & \multicolumn{1}{c|}{ Rendemen } & \multicolumn{1}{c|}{ Peneliti } \\
\hline Kulit cod/Cod leather & $20 \%$ & Sadowska et al. (2003) \\
\hline Kulit sotong/Cuttlefish leather & $\begin{array}{l}2 \% \text { (dry rendemen ASC) } \\
35 \% \text { (dry kering PSC) }\end{array}$ & Nagai et al. (2001) \\
\hline Kulit kakap merah/Baramundy leather & $\begin{array}{l}9 \% \text { (web rendemen ASC) } \\
4,7 \% \text { (web rendemen PSC) }\end{array}$ & Jongjareonak et al. (2004) \\
\hline Sisik sardine/Sardine scale & $50,9 \%$ (dy rendemen PSC) & Nagai et al. (2004) \\
\hline Sisik karper/Carper scale & $7 \%$ (dry rendemen ASC) & Kimura et al. (1991) \\
\hline Sisik Sardin/Sardine scale & $5 \%$ dry rendemen ASC) & Nomura et al. (1996) \\
\hline Kulit nila hitam/Black tilapia leather & $\begin{array}{l}5,97 \% \text { (dry rendemen } \\
\text { ASC) }\end{array}$ & $\begin{array}{l}\text { Sahubawa \& Naro Putra } \\
(2010)\end{array}$ \\
\hline
\end{tabular}

Keterangan/Note:

ASC $=$ Acid Solubilised Collagen

PSC $=$ Pepsin Solubilised Collagen

Tabel 2.

Waktu alir kolagen sampel kulit nila hitam pada kisaran suhu berbeda

\begin{tabular}{|l|l|l|}
\hline \multirow{2}{*}{$\begin{array}{c}\text { Suhu } \\
\left({ }^{\circ} \mathbf{C}\right)\end{array}$} & \multicolumn{2}{|c|}{ Waktu Alir (detik) } \\
\cline { 2 - 3 } & Larutan kolagen (t) & Pelarut $\mathbf{( t}_{\mathbf{0}} \mathbf{)}$ \\
\hline 30 & 203,9 & 192,6 \\
\hline 32 & 196,9 & 186,4 \\
\hline 34 & 186,8 & 179,1 \\
\hline 36 & 177,3 & 172,5 \\
\hline 38 & 169,3 & 166,2 \\
\hline 40 & 159,9 & 160,4 \\
\hline 42 & 154,3 & 154,6 \\
\hline
\end{tabular}

Hasil perhitungan viskositas kolagen (Tabel 3) didasarkan pada hasil pengamatan waktu alir. Makin tinggi suhu, makin menurun viskositas spesifik dan viskositas tereduksi. Viskositas tertinggi didapatkan pada suhu $30^{\circ} \mathrm{C}$ yakni $\eta_{\text {sp }}$ sebesar 0,0587 dan $\eta_{\mathrm{sp}} / \mathrm{c}$ sebesar 2,9334, dengan nilai terendah didapatkan pada suhu $42^{\circ} \mathrm{C}$ yakni $\eta_{\text {sp }}$ sebesar $-0,0019$ dan $\eta_{\text {sp }} /$ c sebesar -0,0970. Viskositas spesifik $\left(\eta_{\mathrm{sp}}\right)$ dihitung dengan persamaan ( $\mathrm{t}$ $\left.t_{0}\right) / t_{0}$, yang mengasumsikan bahwa densitas larutan dan pelarut (asam asetat) adalah sama $\left(\mathrm{t}=\right.$ efflux time larutan kolagen dan $\mathrm{t}_{0}=$ efflux time solven). Viskositas tereduksi $\left(\eta_{\mathrm{sp}} / \mathrm{c}\right)$, dengan $\mathrm{c}$ adalah konsentrasi protein $(\mathrm{g} / \mathrm{dl})$, diplotkan melawan konsentrasi c.

Penurunan viskositas disebabkan oleh penurunan berat molekul kolagen akibat pemutusan rantai polimer. Menurut Kristianto
(2009), hubungan berat molekul polimer dengan viskositas larutannya dapat dilihat pada persamaan Mark-Houwink berikut.

$$
[\eta]=\mathrm{KM}
$$

Ket.:

[ๆ] :viskositas

M :konstanta panjang polimer (berkisar antara $0,5-0,8$ )

$\alpha \quad$ :berat molekul

$\mathrm{K} \quad$ :konstanta jenis polimer

Tabel 3.

Viskositas kolagen sampel kulit nila hitam pada suhu berbeda

\begin{tabular}{|l|l|l|}
\hline Suhu $\left({ }^{\circ} \boldsymbol{C}\right)$ & $\begin{array}{l}\text { Viskositas } \\
\text { Spesifik }\left(\eta_{s p}\right)\end{array}$ & $\begin{array}{l}\text { Viskositas } \\
\text { Tereduksi } \\
\left(\eta_{s p} / \boldsymbol{c}\right)\end{array}$ \\
\hline 30 & 0,05867082 & 2,93354102 \\
\hline 32 & 0,05633047 & 2,81652360 \\
\hline 34 & 0,04299274 & 2,14963707 \\
\hline 36 & 0,02782609 & 1,39130435 \\
\hline 38 & 0,01865223 & 0,93261131 \\
\hline 40 & $-0,00311721$ & $-0,15586035$ \\
\hline 42 & $-0,00194049$ & $-0,09702458$ \\
\hline
\end{tabular}

\section{Suhu Denaturasi}

Kurva denaturasi termal larutan kolagen dibentuk dengan memplotkan viskositas tereduksi $\eta_{\mathrm{sp}} / \mathrm{c}$ melawan suhu. Titik denaturasi, $T d-V$, diekspresikan sebagai suhu pertengahan antara garis terekstrapolasi dari kolagen asal dengan kolagen yang 
sepenuhnya terdenaturasi pada plot $\eta_{s s} / c$ melawan suhu. Suhu denaturasi kolagen kulit nila hitam terukur sebesar $35,75^{\circ} \mathrm{C}$ dengan kurva denaturasi termal seperti diperlihatkan pada Gambar 2.

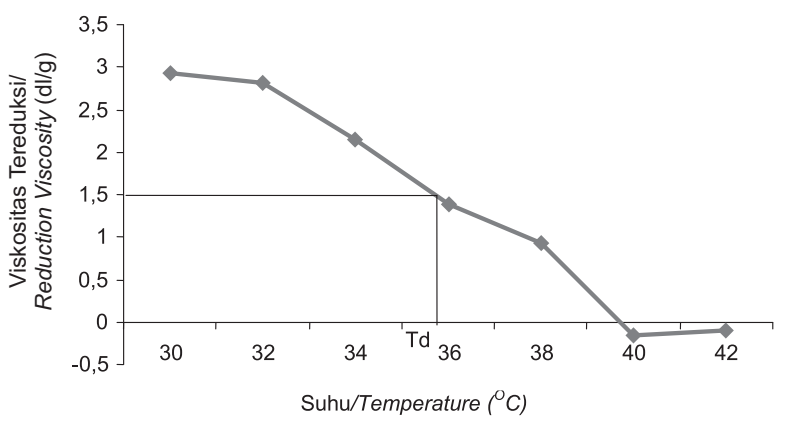

Gambar 2.

Kurva denaturasi termal sampel kolagen kulit nila hitam

Suhu denaturasi kolagen kulit nila hitam dapat berbeda-beda tergantung pada spesies dan habitat ikan (lihat Tabel 4). Kolagen dari ikan perairan dingin umumnya memiliki suhu denaturasi yang lebih rendah dibandingkan yang hidup diperairan tropis. Kestabilan kolagen terhadap suhu merupakan suatu adaptasi fisiologis ikan terhadap suhu lingkungannya (Ogawa et al., 2004).

Menurut Jongjareonrak et al. (2004), kestabilan kolagen dipengaruhi kandungan asam amino (terutama asam amino prolin dan hidroksiprolin). Makin tinggi kandungan prolin dan hidroksiprolin, makin stabil dan tinggi titik denaturasi struktur heliks kolagen. Kolagen dari bahan baku berbeda mempunyai titik denaturasi yang berbeda pula.

\section{Komposisi Asam Amino}

Kolagen mengandung asam amino prolin, glisin, alanin, asam glutamat dan hidroksiprolin dalam jumlah besar (Ogawa et al., 2004). Kolagen juga mengandung metionin, tirosin dan histidin tetapi dalam jumlah kecil serta tidak memiliki triptofan atau sistein (Muyonga et al., 2004). Hasil analisis asam amino kolagen kulit nila dapat dilihat pada Gambar 3.

Pengamatan komposisi asam amino kolagen kulit nila hitam difokuskan pada glisin, alanin dan asam glutamat. Hasil analisis menunjukkan bahwa kolagen kulit nila mengandung glisin 5395,82 ppm, alanin 2979,15 ppm, dan asam glutamat 1684,42 ppm. Berdasarkan hasil penghitungan luas puncak, didapatkan kandungan glisin sebesar 52,9\%, alanin 22,1\% dan asam glutamat 7,4\%. Kandungan glisin dan alanin kulit nilai hitam sangat tinggi dibandingkan dengan glisin dan alanin dari sumber kolagen yang berbeda. Perbandingan komposisi asam amino berbagai macam sumber kolagen dapat dilihat pada Tabel 5.

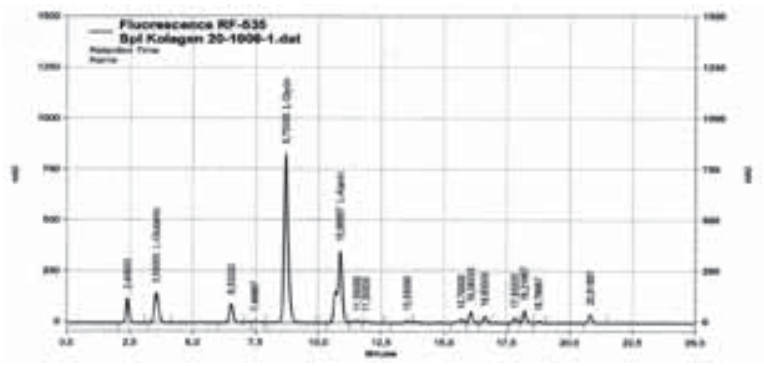

Gambar 3.

Hasil analisis asam amino kolagen kulit nila hitam kering.

Tabel 4.

Suhu denaturasi kolagen berbagai macam bahan baku

\begin{tabular}{|c|c|c|}
\hline Sumber Kolagen & Suhu Denaturasi & Penelit \\
\hline Kulit ikan cod/Cod leather & $15,0^{\circ} \mathrm{C}$ & \multirow{4}{*}{ Muyonga et al., 2004} \\
\hline Kulit belut/Eel leather & $29,3^{\circ} \mathrm{C}$ & \\
\hline Kulit ikan mackerel/Mackeral leather & $26,1^{\circ} \mathrm{C}$ & \\
\hline Kulit ikan cakalang/Skipjack leather & $29,7^{\circ} \mathrm{C}$ & \\
\hline Sirip ikan hiu botol/Bottle shark fin & $25,0^{\circ} \mathrm{C}$ & \multirow{5}{*}{ Nagai et al., 2001} \\
\hline Sisik ikan mas/Scales of goldfish & $32,5^{\circ} \mathrm{C}$ & \\
\hline Tulang ikan kakap/Baramundy bond & $30,0^{\circ} \mathrm{C}$ & \\
\hline Sirip ikan kakap/Baramundi bond & $29,1^{\circ} \mathrm{C}$ & \\
\hline Testis bulu babi/Testis sea urchin & $28,0^{\circ} \mathrm{C}$ & \\
\hline
\end{tabular}




\section{Elektroforesis}

Pola SDS PAGE sampel kolagen kulit nila hitam dapat dilihat pada Gambar 4. Pola tersebut menyerupai hasil pengamatan pada nile perch (Muyonga et al., 2004); blackdrum, sheepshead seabream (Ogawa et al., 2004); dan kakap merah (Jongjareonrak et al., 2004). Pola SDS PAGE menunjukan bahwa kolagen kulit nila hitam memiliki rantai $\alpha$ dan rantai $\beta$ yang tidak dapat teramati secara jelas karena masih tampak berhimpitan. Fenomena tersebut dapat terjadi karena komposisi asam amino rantai -1 dan -2 yang tidak jauh berbeda dengan berat molekul yang relatif sama (Wang et al. 2008).

Tabel 5 .

Perbandingan komposisi asam amino bermacam bahan baku kolagen

\begin{tabular}{|c|c|c|c|c|c|c|c|c|c|}
\hline \multirow[b]{2}{*}{ No } & \multirow[b]{2}{*}{ Asam Amino } & \multicolumn{8}{|c|}{ Sumber Kolagen (per 1000 residu asam amino) } \\
\hline & & $\begin{array}{c}\text { Kulit } \\
\text { babi } \\
(\%)^{a}\end{array}$ & $\begin{array}{l}\text { Sisik } \\
\text { black } \\
\text { drum } \\
(\%)^{b}\end{array}$ & $\begin{array}{c}\text { Kulit } \\
\text { kakap } \\
\text { merah } \\
(\%)^{c}\end{array}$ & $\begin{array}{c}\begin{array}{c}\text { Kulit } \\
\text { sotong }\end{array} \\
(\%)^{d}\end{array}$ & $\begin{array}{c}\text { Tulang } \\
\text { sheepshead } \\
(\%)^{b}\end{array}$ & $\begin{array}{c}\text { Sisik } \\
\text { sardin } \\
(\%)^{e}\end{array}$ & $\begin{array}{c}\text { Sisik } \\
\text { red sea } \\
\text { bream } \\
(\%)^{e}\end{array}$ & $\begin{array}{c}\begin{array}{c}\text { Kulit nila } \\
\text { hitam }\end{array} \\
(\%)^{f}\end{array}$ \\
\hline 1 & Glisin/Glisine & 33,8 & 34,5 & 25,2 & 31,8 & 34,2 & 34,0 & 34,0 & 52,9 \\
\hline 2 & Alanin/Alanine & 11,3 & 12,4 & 14,3 & 8,3 & 12,9 & 11,5 & 11,6 & 22,1 \\
\hline 3 & $\begin{array}{l}\text { Asam glutamate/ } \\
\text { Glutamate Acid }\end{array}$ & 7,8 & 6,4 & 8,1 & 9,2 & 6,6 & 7,1 & 7,2 & 7,4 \\
\hline 4 & Prolin/Proline & 12,6 & 11,1 & 13,1 & 9,8 & 10,6 & 11,1 & 10,9 & $\mathrm{td}^{*}$ \\
\hline 5 & $\begin{array}{l}\text { Hidroksiprolin/ } \\
\text { Hidroxiproline }\end{array}$ & 7,9 & 8,8 & 8,1 & 9,0 & 8,9 & 8,6 & 8,7 & $\mathrm{td}^{*}$ \\
\hline
\end{tabular}

Keterangan:

a Morimura et al. (2001)

b Ogawa et al. (2004)

c Jongjareonrak et al. (2004)

${ }^{d}$ Nagai et al. (2001)

* tidak diamati

e Nagai et al. (2004)

${ }^{\text {f }}$ Sahubawa \& Naro Putra (2010)

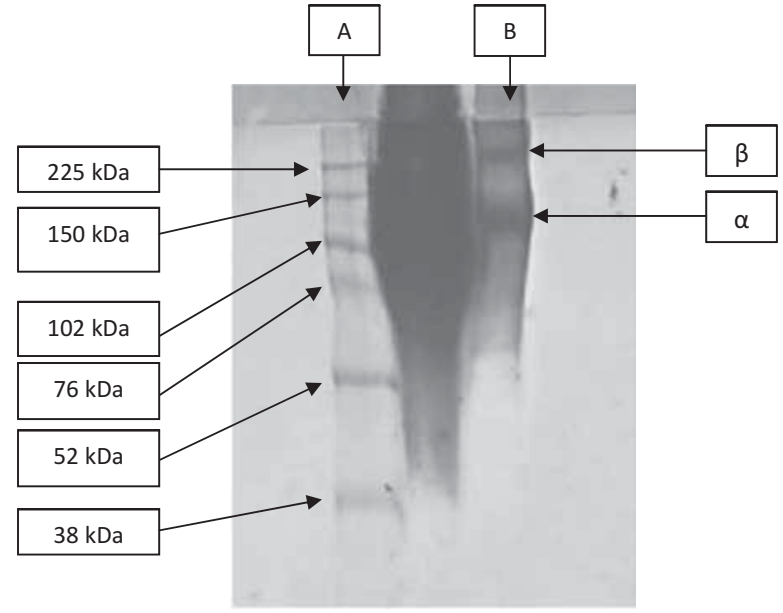

Gambar 4.

Pola SDS polyacrylamide gel (8\%) elektroforesis untuk marker bobot molekul rainbow (sumuran A) dan kolagen sampel kulit nila hitam (sumuran B)

Kolagen sampel kulit nila hitam memiliki rantai $\beta$, yang menunjukan bahwa dalam kolagen ini terdapat komponen terikat-silang (cross-linked components), yaitu terjadinya intra-molecular cross-linking dan/atau intermolecular cross-linking (Ogawa et al., 2004).

\section{SIMPULAN}

1. Perlakuan konsentrasi asam asetat $(0,25 \mathrm{M} ; 0,50 \mathrm{M}$; dan 0,75 M) dan waktu ekstraksi (16 dan 48 jam) tidak berpengaruh nyata terhadap perubahan rendemen kolagen kering. Perlakuan asam asetat $0,75 \mathrm{M}$ dan waktu ekstraksi 16 jam menghasilkan rendemen kering yang tertinggi $(5,97 \%)$ dibandingkan pelakuan lainnya.

2. Kolagen kulit nila hitam memiliki karakteristik: viskositas larutan kolagen menurun sejalan dengan peningkatan suhu; suhu denaturasi $35,75^{\circ} \mathrm{C}$; kandungan asam amino glisin 52,99\%, alanin 22,08\% dan glutamat 7,45\%, termasuk kolagen tipe-I". 
3. Perlu dilakukan penelitian lanjutan dengan konsentrasi asam asetat 0,75\% pada waktu ekstraksi lebih kecil dari 16 jam untuk melihat pengaruhnya terhadap persentase rendemen kolagen.

\section{DAFTAR PUSTAKA}

Basmal, J., P. Agung, dan Y. Farida. 2007. Pengaruh Suhu Esterifikasi terhadap Kualitas dan Kuantitas Kitosan Larut Air yang Dibuat dari Cangkang Rajungan. Jurnal Pascapanen dan Bioteknologi Kelautan dan Perikanan. 2 (2): 99-106.

Basmal, J., P. Agung, dan Y.N. Fawzya. 2005. Pengaruh Konsentrasi Asam Monokloroasetat dalam Proses Karboksimetilasi Kitosan terhadap Karboksimetil Kitosan yang Dihasilkan. Jurnal Penelitian Perikanan Indonesia. 11(8): 47-55.

Billmeyer, F.W. 1962. Textbook of Polymer Science. Interscience Publisher, New York.

Chvapil, M. 1979. Industrial uses of collagen. In: D.A.D. Parry and L.K. Creamer (Eds.) Fibrous Protein: Scientific, Industrial and Medical Aspects. Academic Press, New York, p: 247267.

Departemen Kelautan dan Perikanan. 2009. Nila Andalan Produk Perikanan. Naskah Siaran Pers No. B. 113/PDSI/ HM.310/XI/2009.

Jongjareonrak, A., S. Benjakul, W. Visessanguan, T. Nagai, and M. Tanaka. 2004. Isolatioan and characterisation of acid and pepsinsolubilised collagens from the leather of browns-tripe red snapper (Lutjanus vitta). Food Chemistry.

Kimura, S., Y. Miyauchi, dan N. Uchida. 1991. Scale and BoneType I Collagens of Carp (Cyprinus carpio). Comparative Biochemistry and Physiology 99B: 473-476.
Kristianto, M.I. 2009. Presipitasi Kitosan Cangkang Rajungan dengan $\mathrm{NaOH}$ dalam Sintesis Karboksimetilkitosan. Fakultas Pertanian. Universitas Gadjah Mada. Skripsi.

Morimura, S., H. Nagata, Y. Uemura, A. Fahmi, T. Shigematsu, and K. Kida. 2002. Development of an Effective Process for Utilization of Collagen from Livestock and Fish Waste. Process Biochemistry. 37: 403-142.

Muyonga, J.H., C.G.B. Cole, and K.G. Duodu. 2004. Characterisation of Acid Soluble Collagen from Leathers of Young and adult Nile Perch (Lates niloticus). Food Chemistry. 85: 81-89.

Nagai, T., E. Yamashita, K. Taniguchi, N. Kanamori, and N. Suzuki. 2001. Isolation and Characterization of Collagen from The Outer Leather Waste Material of Cuttlefish (Sepia Lycidas). Food Chemistry. 72: 425-429.

Nagai, T., M. Izumi, and M. Ishii. 2004. Fish Scale Collagen Preparation and Partial Characterization. International Journal of Food Science and Technology. 39: 239-244.

Nielsen, S.S. 2003. Food Analysis Laboratory Manual. Kluwer Academic / Plenum Publishers, New York.

Nomura, Y., H. Sakai, Y. Ishii, dan K. Shirai. 1996. Preparation and Some Properties of Type I Collagen from Fish Scales. Bioscience, Biotechnology, and Biochemistry. 60: 2092-2094.

Ogawa, M., R.J. Portier, M.W. Moody, J. Bell, M.A. Schexnayder, and J.N. Losso. 2004. Biochemical Properties of Bone and Scale Collagens Isolated from The Subtropical Fish Black Drum (Pogonia cromis) and Sheepshead Seabream (Archosargus probatocephalus). Food Chemistry. 88: 495-501.

Rehn, M., T. Veikkola, E. Kukk-Valdre, H. Nakamura, M. Ilmonen, C. 
Lombardo, T. Pihlajaniemi, K. Alitalo, and K. Vuori. 2001. Interaction of Endostatin with Integrins Implicated in Angiogenesis. Proceedings of the National Academy of Sciences of the USA. 98: 1024-1029.

Sadowska, M., I. Kolodziejska, and C. Niecikowska. 2003. Isolation of Collagen from the Leathers of Baltic Cod (Gadus morhua). Food Chemistry. 81: 257-262.
Sambrook, J. and D. W. Russel. 2001. Molecular Cloning: A Laboratory Manual. CHSL Press. New York.

Sudarmadji, S. 1996. Teknik Analisa Biokimiawi. Penerbit Liberty, Yogyakarta.

Wang, L., X. An, F. Yang, Z. Xin, L. Zhao, Q. Hu. 2008. Isolation and characterisation of collagens from leather, scale and bone of deep-sea redfish (Sebastes mentella). Food Chemistry 108: 616-623.

Yamaguchi, K. 2002. Bovine Spongiform Encephalopathy and People. Iwanami Press, Tokyo. 